BRIEF REPORTS

\title{
Biting the hand that feeds you: wedge-billed hummingbird is a nectar robber of a sicklebill- adapted Andean bellflower
}

\author{
Mannfred M.A. BOEHM ${ }^{1, *}$ \\ 1 University of British Columbia, Department of Botany, Biodiversity Research Centre, Vancouver, BC, V6T 1Z4, Canada. \\ * Corresponding author: mannfred.boehm@ubc.ca
}

\section{ABSTRACT}

I report on nectar robbing behavior of the wedge-billed hummingbird (Schistes geoffroyi Trochilidae) on the Andean bellflower Centropogon granulosus (Campanulaceae). Many species of Centropogon are characterized by an abruptly curved corolla tube which is likely specialized for pollination by sicklebill hummingbirds (Eutoxeres), as evident from the matching curvature of flower and bill. Nectar robbing has been documented for some Centropogon spp., but not for sicklebill pollinated C. granulosus. Given recent developments and interest in the Centropogon-sicklebill mutualism, it is pertinent to document any natural history observations that may underlie the ecology and evolution of this pollination system. The establishment of wedgebilled hummingbird as a nectar robber of $C$. granulosus calls for a new assessment of the ecology and evolution of the highly specialized Centropogon-sicklebill mutualism.

KEYWORDS: Nectar robbing, bird pollination, neotropical bellflowers, Schistes geoffroyi, co-evolution

\section{Muerde la mano que le da de comer: Colibrí pico cuña el ladrón de néctar de Centropogon granulosus (Campanulaceae)}

\section{RESUMEN}

Informo sobre el comportamiento de robo de néctar del colibrí pico cuña (Schistes geoffroyi Trochilidae) en la flor campanulada neotropical Centropogon granulosus (Campanulaceae). Muchas especies de Centropogon se caracterizan por tener una flor tubular curvada de distintas formas y probablemente especializadas para ser polinizadas por los colibríes de pico curvo (Eutoxeres), como es evidente a partir de la curvatura tanto de la flor como del pico. Debido a la exclusividad de este mutualismo, el robo de néctar ha sido ocasionalmente documentado en Centropogon. Aquí amplío el estudio de robo de néctar de Centropogon incluyendo a Schistes geoffroyi. Esta expansión puede ser un indicador de la alta especialización entre el mutualismo de Centropogon y el colibrí de pico curvo, siendo esta más susceptible al robo de néctar previamente pensado. Esto genera preguntas acerca la evolución de la especialización y parasitismo en este grupo tropical tanto de las campanuladas como de los colibríes.

PALABRAS-CLAVE: ladrón de néctar, polinización por aves, campanulada neotropical, Schistes geoffroyi, coevolución 
The Andean bellflowers Centropogon C. Presl (Campanulaceae) are widespread, but especially conspicuous in the montane rainforests of the eastern Andes, with certain species notable for their hook-shaped corolla, ranging from bright pink to red and orange in colour. While Centropogon contains over 200 species (Lagomarsino et al. 2014) occurring from Central America and throughout equatorial South America, it is epitomized by Centropogon granulosus C. Presl (Figure 1). Centropogon granulosus are readily found in treefall gaps, roadsides, and other forest edges in San Pedro, Peru - the area of interest to this study. Centropogon granulosus has long thought to be pollinated by sicklebill hummingbirds (Eutoxeres Bourcier, Phaethornithinae Jardine) a genus of two hummingbird species characterized by bills equally dramatic in their curvature (Stein 1992). Although nectar robbing has been occasionally documented in Centropogon, the only reports of nectar robbing in a curved-flower Centropogon sp. are of Phaethornis squalidus Temminck and Glaucis hirsutus Gmelin (Muruyama et al. 2015) - two hermit hummingbirds (Phaethornithinae) with relatively long and curved bills.

During a pollination study of Centropogon granulosus, I recorded nectar robbing by the wedge-billed hummingbird (Schistes geoffroyi Bourcier, Trochilinae Jardine). The study site is located in Paucartambo Province, on the eastern slopes of the Peruvian Andes. This site is locally known as 'San Pedro' (approximately $13^{\circ} 3^{\prime} 21.0564$ ” S, $71^{\circ} 32^{\prime} 46.9133^{\prime \prime} \mathrm{W}$, and 1300 m.a.s.l.) and is about $60 \mathrm{~km}$ north-east of the city of Cusco. Eight camera traps were deployed for two months of daily monitoring within 4:00 to 20:00. Camera traps were moved to previously unmonitored Centropogon granulosus patches every seven days. Eutoxeres condamini Bourcier was the only other vertebrate visitor to Centropogon granulosus.

On September 2 $2^{\text {nd }}$, 2017, at 14:57 PET a Schistes geoffroyi individual approached an inflorescence of Centropogon granulosus and inserted its bill into the base of the flowers, instead of entering at the opening of the corolla (Figure 1). It then proceeded systematically to visit nearby Centropogon granulosus inflorescences, exhibiting the same behavior. Following the bird's

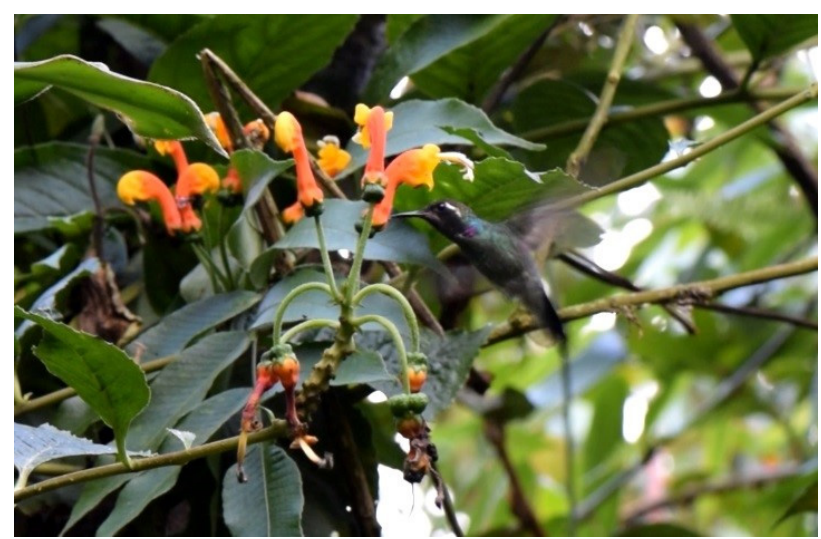

Figure 1. Schistes geoffroyi probing the base of the corolla of Centropogon granulosus. Taken at San Pedro, outside of the Manú National Park, Peru. This figure is in colour in the electronic version. departure, inspection of the flowers revealed fresh punctures at the base of the corollas (Figure 2). It is presumed these punctures were made by Schistes geoffroyi because no other nectar robbers were recorded in camera traps, and typical flower-piercing species (e.g. Diglossa Wagler) do not occur at this elevation in this region (Jankowski et al. 2013). Nectar concentration was measured from four flowers that had recently undergone anthesis, using an ATC handheld Brix refractometer. The mean nectar sugar concentration was found to be $24.9 \pm 1.3 \%(95 \%$ C.I., $n=4)$; this is typical of sugar concentrations found in other bird pollinated plant taxa (Bolten and Feinsinger 1978). Four video recordings of nectar robbery of Centropogon granulosus by wedge-billed hummingbird were made over the month of September, and numerous other instances were documented without video. Recordings are available at https://vimeo.com/ mannfred (contact author for additional footage). Patches of Centropogon granulosus with at least one documented visit were very likely to have further visits by wedge-billed hummingbirds, suggesting territory holding behavior. As no birds were marked or had distinguishing individual features, it is unclear whether the observed visits were made by the same or separate individuals.

The diet of Shistes geoffroyi is composed of both arthropods (Remsen et al. 1986), and nectar that is primarily obtained from piercing flowers (Walther and Brieschke 2001; Hilty 2003). Generally, hummingbirds are thought to acquire nectar as legitimate pollinators, however, an increasing number of cases demonstrate the contrary. Fiery-throated hummingbirds (Panterpe insignis Cabanis \& Heine) have been reported to follow passerine flower piercers in order to drink from the holes made in robbed flowers (Stiles 1983), volcano hummingbirds (Selasphorus flammula Salvin) pierce or use holes in Centropogon made by slaty flowerpiercers (Diglossa plumbea Cabanis) (Henderson 2002), and reddish hermit (Phaethornis ruber L.) engages in some form of floral larceny in nearly a third of the plant species it visits (Maruyama et al. 2015). Hilty (2003) describes the wedge-billed hummingbird as a 'notorious nectar thief', visiting Fuchsia L., Cavendishia Lindl., Palicourea Aubl., and Centropogon,

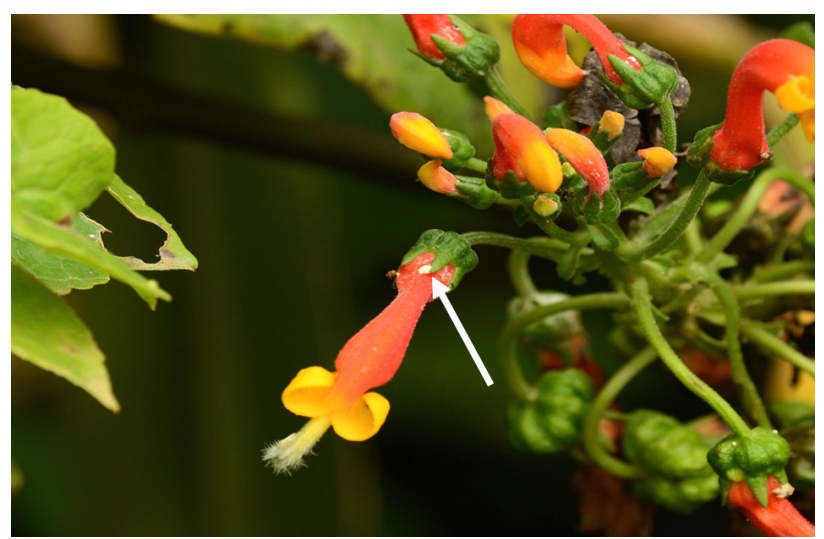

Figure 2. Latex exuding from the base of a corolla of Centropogon granulosus following a visit from Schistes geoffroyi. This figure is in colour in the electronic version. 
although species-level descriptions are absent. Additionally, there is evidence that, in general, short-billed hummingbirds are more likely to be nectar robbers of long corolla tubes that have coadapted to long-billed hummingbirds (Feinsinger et al. 1987, Lara and Ornelas, 2001). An analysis of bill measurement data collected from ongoing mist netting efforts in San Pedro reveal Schistes geoffroyi to have the second shortest bill of the 24 hummingbirds found in the region (M. Scholer, unpublished data). Given its tendency to pierce flowers (Walther and Brieschke 2001; Hilty 2003), and serrated upper-bill (Ornelas 1994), wedge-billed hummingbird appears to be a species especially adapted to nectar robbing.

A notable trait of Centropogon and other neotropical Campanulaceae is the secretion of a milky white latex from damaged tissues, including floral tissue, which over an hour turns brown or black as it dries. This latex is irritating to the touch and may be an adaptation to deter herbivory (Mabberley 1975). Whether the latex of all Campanulaceae is an adaptation to deter herbivory remains unknown; nonetheless the above observations suggest that Schistes geoffroyi is not deterred or severely affected by the presence of latex in Centropogon granulosus.
Several Centropogon spp. are widely presumed to be adapted for pollination by sicklebill hummingbirds because the curvature of the bird's bill appears to fit the hook-shaped flowers like a lock and key' (Stein 1992). Further evidence supporting hummingbird pollination can be found in the method of pollen dispersal: the floral trichomes of Centropogon granulosus are fused into a scale that covers the anthers. When the scale is pushed back pressurized pollen is released. This trap door mechanism ensures effective placement of the pollen on to the head of a visiting bird (likely Eutoxeres: Stein 1992) and protects the pollen from insects unable to open the scale. Two days following the opening of the flower, the stigma extends past the scale, temporally separating the male and female phase of the flower, and allowing pollen to be deposited from bird to plant.

Despite the compelling, morphological and phenological evidence, it remains that little documentation of sicklebills visiting Centropogon exist, though accounts of nectar robbing in Centropogon have been documented (Table 1). If in fact Centropogon granulosus is pollinated by Eutoxeres, there are potential evolutionary and ecological implications of nectar robbing for both species, including decreased nectar quality

Table 1. Documented or proposed hummingbird visitors to Centropogon

\begin{tabular}{|c|c|c|c|c|}
\hline Centropogon species & Flower shape & Visitor & Visitor Type & Reference \\
\hline \multirow{3}{*}{ Centropogon valerii } & \multirow{3}{*}{ Long, slightly curved } & Colibrithalassinus & Pollinator & Colwell et al. 1974 \\
\hline & & Eugenes fulgens & Pollinator & Colwell et al. 1973 \\
\hline & & Panterpe insignis & Pollinator & Colwell et al. 1973 \\
\hline Centropogon granulosus & Medium length, very curved & Eutoxeres spp. & Pollinator & Stein 1992 \\
\hline Centropogon baezanus & Medium length, very curved & Eutoxeres spp. & Pollinator & Stein 1987 \\
\hline \multirow{2}{*}{ Centropogon talamancensis } & \multirow{2}{*}{ Long, straight } & Eugenes fulgens & Pollinator & Wolf et al. 1976 \\
\hline & & Panterpe insignis & Nectar robber $\left(1^{\circ}\right)$ & Colwell et al. 1973 \\
\hline Centropogon ferrugineus & Medium length, curved & Lafresnaya lafresnayi & Pollinator & Toloza-Moreno et al. 2015 \\
\hline Centropogon costaricae & Long, slightly curved & Trochildae (species not indicated) & Pollinator & Fenster 1991 \\
\hline \multirow{4}{*}{ Centropogon cornutus } & \multirow{4}{*}{ Medium length, very curved } & Ramphodon naevius & Pollinator & Buzato et al. 2000 \\
\hline & & Phaethornis eurynome & Pollinator & Buzato et al.,2000 \\
\hline & & Phaethornis squalidus & Nectar robber (mode not specified) & Maruyama et al. 2015 \\
\hline & & Glaucis hirsutus & Nectar robber (mode not specified) & Maruyama et al. 2015 \\
\hline \multirow{7}{*}{ Centropogon } & \multirow{7}{*}{ NA } & Schistes geoffroyi & Nectar robber $\left(1^{\circ}\right)$ & Hilty 2003 \\
\hline & & Panterpe insignis & Nectar robber $\left(1^{\circ}\right.$ and $\left.2^{\circ}\right)$ & Henderson 2002 \\
\hline & & Selasphorus flammula & Nectar robber $\left(2^{\circ}\right)$ & Henderson 2002 \\
\hline & & Colibri thalassinus & Not specified & Henderson 2002 \\
\hline & & Lampornis castaneoventris & Not specified & Henderson 2002 \\
\hline & & Phaethornis guy & Pollinator & Snow and Snow 1972 \\
\hline & & Glaucis hirsutus & Pollinator & Snow and Snow 1972 \\
\hline
\end{tabular}


and quantity, lower seed set, and modified pollinator behavior (Colwell et al. 1974; Traveset et al. 1998; Kjonaas and Rengifo 2006; Hazlehurst and Karubian 2016). In the latter case, nectar robbing may decrease the per-flower reward for legitimate pollinators, leading to increased flight distance to fulfil their energetic needs, ultimately promoting outcrossing (Hazlehurst and Karubian 2016). While nectar robbing is well studied (reviewed in Irwin et al. 2010), it remains unknown whether plant-bird specializations are the cause or result of cheating (by either birds or invertebrates). An analysis of divergence times indicates that Eutoxeres existed for nearly 20 million years before the emergence of the eucentropogonids (sensu Lagomarsino et al. 2014), and that curvature is an adaptation that first co-evolved with Heliconia (Abrahamczyk et al. 2017). However, it is unclear whether curvature (and therefore specialization) evolved to ensure pollination in a Centropogon sp. experiencing a high degree of nectar thievery (sensu Irwin et al. 2010), or whether the evolution of curvature has triggered nectar robbing among those hummingbirds that are now excluded from entering the corolla tube from the opening. In light of this, I posit that nectar robbing in sicklebill-pollinated Centropogon could be more widespread than is currently realized, and future studies will benefit from a focus on the effects of nectar robbing on reproductive fitness in Centropogon.

\section{ACKNOWLEDGEMENTS}

I would like to thank Micah N. Scholer, Julian Heavyside, Jeremiah J.C. Kennedy, David Guevara Apaza, Elizabeth Llacta Cuno, Quentin C.B. Cronk, Jill E. Jankowski, and the four anonymous reviewers for their helpful comments in improving this manuscript. This expedition was made possible by funding from the Natural Sciences and Engineering Research Council of Canada (NSERC) Discovery Grants to Quentin Cronk (RGPIN-2014-05820) and Jill Jankowski at the University of British Columbia (RGPIN-2012-418294), a Walter H. Lewis Award in Plant Biodiversity from the UBC Herbarium, and the expert advice from the staff of Universidad Nacional Agraria la Molina, Universidad Nacional San Antonio Abad del Cusco, and Perú Verde.

\section{REFERENCES}

Bolten, A.B.; Feinsinger, P. 1978. Why do hummingbird flowers secrete dilute nectar? Biotropica, 10: 307-309.

Buzato, S.; Sazima, M.; Sazima, I. 2000. Hummingbird-pollinated floras at three Atlantic forest sites. Biotropica, 32: 824-841.

Colwell, R. K. 1973. Competition and coexistence in a simple tropical community. The American Naturalist, 107: 737-760.

Colwell, R.K.; Betts, B.J.; Bunnell, P.; Carpenter F.L.; Feinsinger, P. 1974. Competition for the nectar of Centropogon valerii by the Hummingbird Colibri thalassinus and the Flower-piercer Diglossa plumbea, and its evolutionary implications. The Condor, 76: 447-452.

Feinsinger, P.; Beach, J.H.; Linhart, Y.B.; Busby, W.H.; Murray, G. 1987. Disturbance, pollinator predictability, and pollination success among Costa Rican cloud forest plants. Ecology, 68: 1294-1305.

Fenster, C.B. 1991. Selection of floral morphology by hummingbirds. Biotropica, 23: 98-101.

Hazlehurst, J.A.; Karubian, J.O. 2016. Nectar robbing impacts pollinator behavior but not plant reproduction. Oikos, 125: 1668-1676.

Henderson, C.L. 2002. Field Guide to the Wildlife of Costa Rica. University of Texas Press, Austin, Texas. p.277-292.

Hilty, S.L. 2003. Birds of Venezuela. A\&C Black Publishers Ltd., London, England. 433p.

Irwin, R.E.; Bronstein, J.L.; Manson, J.S.; Richardson, L. 2010. Nectar robbing: Ecological and evolutionary perspectives. Annual Review of Ecology, Evolution, and Systematics, 41: 271-292.

Jankowski, J.E.; Merkord, C.L.; Farfan Rios, W.; García Cabrera, K.; Salinas Revilla, N.; Silman, M.R. 2013. Journal of Biogeography, 40: 950-962.

Kjonaas, C.; Rengifo, C. 2006. Differential effects of avian nectarrobbing on fruit set of two Venezuelan Andean cloud forest plants. Biotropica, 38: 276-279.

Lagomarsino, L.P.; Antonelli, A.; Muchhala, N.; Timmermann, A.; Mathews, S.; Davis, C.C. 2014. Phylogeny, classification, and fruit evolution of the species-rich Neotropical bellflowers (Campanulaceae: Lobelioideae). American Journal of Botany, 101: 2097-2112.

Lagomarsino, L.P.; Condamine, A.A.; Antonelli, A.; Mulch, A.; Davis, C.C. 2016. The abiotic and biotic drivers of rapid diversification in Andean bellflowers (Campanulaceae). New Phytologist, 210: 1430-1442.

Lara, C.; Ornelas, J.F. 2001. Preferential nectar robbing of flowers with long corollas: experimental studies of two hummingbird species visiting three plant species. Oecologia, 128: 263-273.

Mabberley, D.J. 1975. The giant lobelias: toxicity, inflorescence and tree-building in the Campanulaceae. New Phytologist, 75: 289-295.

Maruyama, P.K.; Vizentin-Bugoni, P.; Dalsgaard, B.; Sazima, I.; Sazima, M. 2015. Nectar robbery by a hermit hummingbird: association to floral phenotype and its influence on flowers and network structure. Oecologia, 178: 783-793.

McGuire, J.A.; Witt, C.C.; Remsen, J.V. Jr.; Corl, A.; Rabosky, D.L.; Altshuler, D.L.; Dudley, R. 2014. Molecular phylogenetics and the diversification of hummingbirds. Current Biology, 24: 910-916.

Muchhala, N.; Thomson, J.D. 2010. Fur versus feathers: pollen delivery by bats and hummingbirds and consequences for pollen production. The American Naturalist, 175: 717-726.

Ornelas, J.F. 1994. Serrate tomia: an adaptation for nectar robbing in hummingbirds? The Auk, 111: 703-710. 
Remsen, J.V.; Stiles, F.G.; Scott, P.E. 1986. Frequency of arthropods in stomachs of tropical hummingbirds. The Auk, 103: 436-441.

Snow, B.K.; Snow D.W. 1972. Feeding niches of hummingbirds in a Trinidad Valley. Journal of Animal Ecology, 41: 471-485.

Stein, B. A. 1987. Systematics and evolution of Centropogon subgenus Centropogon (Campanulaceae-Lobelioideae). Ph.D. dissertation, Washington University, Washington, USA. 32p.

Stein, B.A. 1992. Sicklebill Hummingbirds, Ants, and Flowers. BioScience, 42: 27-33

Stiles, F. G. 1983. Species accounts - Birds. In: D. H. Janzen (Ed.). Costa Rican Natural History University of Chicago Press, Chicago, Illinois, p.593-594.

Toloza-Moreno, D.L.; León-Camargo, D.A.; Rosero-Lasprilla, L. 2015. El ciclo anual de una comunidad de colibríes (Trochilidae) en bosques altoandinos intactos y paramizados en la Cordillera Oriental de Colombia. Ornitología Colombiana, 14: 28-47

Traveset, T.; Willson, M.F.; C. Sabag. 1998. Effect of nectarrobbing birds on fruit set of Fuchsia magellanica in Tierra Del Fuego: a disrupted mutualism. Functional Ecology, 12: 459-464.

Walther, B.A.; Brieschke, H. 2001. Hummingbird-flower relationships in a mid-elevation rainforest near Mindo, northwestern Equador. International Journal of Ornithology, 4: 115-135.

Wolf, L.L.; Stiles, F.G.; Hainsworth, R. 1976. Ecological organization of a tropical, highland hummingbird community. Journal of Animal Ecology, 45: 349-379.

RECEIVED: $15 / 11 / 2017$

ACCEPTED: 18/01/2018

ASSOCIATE EDITOR: Sérgio Henrique Borges 